\title{
Family Planning Village Program and Village Community Empowerment in Deli Serdang Regency, North Sumatera Province, Indonesia
}

\author{
Badaruddin $^{1 *}$, Lusiana Andriani Lubis ${ }^{2}$, Humaizi $^{3}$, Klaudia Evinta Siregar ${ }^{4}$ \\ 1, 2, 3, ${ }^{4}$ Universitas Sumatera Utara, Medan, Indonesia \\ Email: badaruddin@usu.ac.id
}

\begin{abstract}
The Family Planning Program was one of the programs in the New Order Era which was considered successful in reducing the rate of population growth in Indonesia. At the beginning of the Reformation Era, attention to the Family Planning Program weakened and the impact on the rate of population growth was increasing. To anticipate, President Jokowi asked the National Population and Family Planning Agency to re-invigorate the Family Planning Program through the Family Planning Village Program Policy. The the Family Planning Village Program is a cross-sectoral program with the aim of reducing birth rates, improving reproductive health, and empowering communities in order to improve their welfare. This study aims to see how the Family Planning Village Program contributes to the empowerment of rural communities. The research design used combination of qualitative and quantitative approaches with a dominant-less dominant model, where the qualitative approach is used as the dominant approach, while the quantitative approach is the less dominant. The number of respondents in this study were 300 people, while the informants consisted of the village government, the management of the Family Planning Village, community leaders and religious leaders. The research results show was conducted in three Family Planning Villages in the three subdistricts in Deli Serdang Regency, North Sumatera Province. The results showed that there were changes that occurred in the three villages studied after the implementation of the Family Planning Village Program. These changes can be seen, among others, from the increasing awareness of the village community in terms of health, both for women who are still productive and the elderly. Mothers of productive age routinely check their pregnancy at the Community Health Center or at the Integrated Service Post. For elderly residents, they also have awareness to live a healthy life after receiving an explanation of services from the health side through the Elderly Family Development Program. Changes also occur in teenagers through the Youth Information and Counseling Center Program, so that they get good and correct information about reproduction so as to reduce early marriage, and avoid the dangers of drugs. Meanwhile, for economic empowerment, through the Prosperous Family Income Improvement Program, villagers also receive counseling and plant seeds that can be used as an additional source of income. Cross-sectoral programs that are the advantages of the Family Planning Program have begun to be seen, but have not been maximized, so there is still a view that the Family Planning Village is a program of the National Population and Family Planning Agency or the Regional Family Planning Agency alone, even though the Family Planning Village should be the responsibility of all parties (Device Organization Region) according to the needs of each village community in the context of the success of the Family Planning Program and the welfare of the community.
\end{abstract}

\section{Keywords: Family Planning Village Program, Cross Sectoral, Empowerment, Community Welfare}

\section{INTRODUCTION}

Based on data presented by the National Population and Family Planning Agency, it can be seen that Indonesia's population growth rate currently reaches 1.49 percent, whereas the government targets population growth to be reduced to 1.1 percent. With such a population growth rate, it is predicted that in 2020-2030, the population of productive age will be very large. Seeing the fact of this population explosion, the Family Planning program was planned again through the Family Planning Village Program (Village FP).

The establishment of this Village FP aims to improve the quality of life of the community at the village level or equivalent, as well as develop related sectors in order to create quality small families. In line with the achievement of the goals and objectives of the Village FP program, the Deli Serdang Regency Government has established and implemented the Village FP program in several villages that are its administrative areas, as a follow-up to the decentralization of the family planning sector. The Deli Serdang Regency Government has so far established 45 Village FP, but no significant results have been seen from this program. A number of research results show that the use of social capital in various development programs shows better results than development programs that ignore social capital. 
The results of research by Badaruddin, et al[1] found that Village Owned Enterprises can improve the welfare of rural communities if Village Owned Enterprises are managed properly. One way to manage Village Owned Enterprises well is to utilize social capital. Research results Badaruddin, et al. [2] concluded that the potential forms of social capital are: first, the potential for social capital in the form of value and the potential for social capital in the form of institutions (formal and non-formal institutions). The management of the Village FP Program that utilizes the potential of existing social capital is expected to be able to achieve the expected goal, namely the ongoing community empowerment that is able to prosper the village community, especially related to family welfare. This study aims to find out how the Village FP Program runs its program to empower rural communities.

\section{LITERATURE REVIEW}

Law Number 52 of 2009 concerning Population Development and Family Development as the basis for implementing population and family planning programs that emphasizes the authority of the National Population and Family Planning Agency (NPFPA). Through this law, the NPFPA does not only focus on population control issues but also on family development issues. The Village FP program is an example of the full implementation of the FPFD (Family Planning and Family Development) plan, which aims to accelerate the development plan agenda, especially in the suburbs[3]. The presence of Village FP aims to improve the quality of life of the community at the village level or its equivalent through the FPFD (Family Planning and Family Development) program as well as the development of other sectors in order to create quality small families with reference to eight family functions. The principle of the FPFD Program (Family Planning and Family Development) is to create a happy and prosperous small family that is free from poverty, fall and backwardness [4]. In 2021 as many as 16,626 villages are the locations or implementation of the Village FP program. The Family Planning Village Program in North Sumatra is 842 villages. The largest family planning village program in North Sumatra is located in Deli Serdang Regency as many as 45 villages have implemented this program[5].

The Village FP program is a form of community empowerment effort in achieving quality small family welfare. According to Eddy Papilaya quoted by Zubaedi[6], empowerment is an effort to build community capabilities by encouraging, motivating, raising awareness of their potential, and trying to develop that potential into real action. In practice, empowerment as a process is carried out in stages and takes a long time and is not carried out through quick results. This is in line with what was stated by Noor [7] who stated that the core of community empowerment includes: development (enabling), strengthening potential or power (empowering), and the creation of independence. According to Ambar Teguh Sulistiyani in Muslim [8], that the stages that must be passed in empowerment are the stage of awareness and behavior formation, the transformation of knowledge or skills, and the stage of increasing intellectual abilities and skills skills.

Furthermore, Ife argues that there are two important points in the implementation of empowerment, namely the delegation of power and the weak group. Power is related to personal choices or life opportunities, being able to decide the needs of life according to the ideas possessed by individuals, the ability to access formal, non-formal, and reproductive institutions and resources [9]. Jim Ife and Frank [10], also explained that empowerment focuses on educative or learning processes for communities to increase their empowerment, so that people have ideas, understanding, vocabulary, and work skills to achieve effective and sustainable changes for their survival.

\section{RESEARCH METHOD}

The research design used in this study is a combination of qualitative and quantitative approaches. The combination model used in this study is a dominant-less dominant design, where the qualitative approach is used as the dominant (qualitativedominant), while the quantitative approach is used as the less dominant (quantitative-less dominant) [11], [12]. The population of this study were families who were in the research location who were involved with the Village FP program. The number of samples used as respondents in this study was 50 respondents for each village, by making the head of the family as the respondent. The sample in this study were 150 respondents. Informants in this study were stakeholders, managers, community leaders, and village government in the program of Village FP. This research was conducted in 3 villages in 3 sub-districts in Deli Serdang Regency, North Sumatera Province, namely: Gunung Meriah District; Percut Sei Tuan District; and Galang District.

\section{RESULTS AND DISCUSSIONS}

The Village FP program in Deli Serdang Regency has been able to provide benefits to the community in an effort to improve family welfare through empowerment carried out by managers and various other parties. Based on the research findings, there are community empowerment efforts in the implementation of the Village FP program, while the stages carried out by the management include three stages, namely awareness, behavior formation, and skill improvement.

\subsection{Public Awareness Through Socialization and Education to the Community}

Community empowerment is associated as a process in village development related to strengthening the 
capacity of the community to be able to improve the situation starting through the family. Socialization is part of the empowerment process, or the awareness stage [13]. Through socialization, it is hoped that it can provide awareness and raise awareness of good knowledge, foster changes in people's attitudes and behavior. Based on the findings of the study, that the management has carried out socialization to the village community. This is contained in Table 4.1.

Tabel 4.1. The Socialization of the KB Village Program Has Been Well Socialized to All Residents

\begin{tabular}{|c|c|c|c|c|c|c|c|c|}
\hline \multirow{3}{*}{ Perception } & \multicolumn{6}{|c|}{ Village FP } & \multirow{2}{*}{\multicolumn{2}{|c|}{ Total }} \\
\hline & \multicolumn{2}{|c|}{$\begin{array}{l}\text { Marjanji } \\
\text { Tongah } \\
\text { Village } \\
\text { (Gunung } \\
\text { Meriah } \\
\text { District) }\end{array}$} & \multicolumn{2}{|c|}{$\begin{array}{c}\text { Tanjung } \\
\text { Rejo Village } \\
\text { (Percut Sei } \\
\text { Tuan } \\
\text { District) }\end{array}$} & \multicolumn{2}{|c|}{$\begin{array}{l}\text { Kramat } \\
\text { Gajah } \\
\text { Village } \\
\text { (Galang } \\
\text { District) }\end{array}$} & & \\
\hline & $F$ & $\%$ & $\mathrm{~F}$ & $\%$ & $\mathrm{~F}$ & $\%$ & $\mathrm{~F}$ & $\%$ \\
\hline $\begin{array}{l}\text { Strongly } \\
\text { Disagree }\end{array}$ & 0 & 0,0 & 0 & 0,0 & 0 & 0,0 & 0 & 0,0 \\
\hline \begin{tabular}{|l|} 
Don't \\
Agree
\end{tabular} & 1 & 0,7 & 8 & 5,3 & 1 & 0,7 & 10 & 6,7 \\
\hline Doubtful & 8 & 5,3 & 13 & 8,7 & 18 & 12,0 & 39 & 26,0 \\
\hline Agree & 23 & 15,3 & 15 & 10,0 & 17 & 11,3 & 55 & 36,7 \\
\hline $\begin{array}{l}\text { Strongly } \\
\text { Agree }\end{array}$ & 18 & 12,0 & 14 & 9,3 & 14 & 9,3 & 46 & 30,7 \\
\hline Total & 50 & 33,3 & 50 & 33,3 & 50 & 33,3 & 150 & 100 \\
\hline
\end{tabular}

Source: Research data has been processed, 2021

Table 4.1. shows that, of the 150 respondents who became research respondents, as many as 101 respondents $(67.3 \%)$ stated that the Village FP administrators had socialized to the community about the Village FP program in their village. However, there were still respondents who expressed doubt that the management had conducted socialization to them, namely 39 respondents $(26.0 \%)$, and 10 respondents $(6.7 \%)$ answered that they did not agree. This finding illustrates that the Village FP administrators have not been maximal in socializing the existence of the Village FP program in their village. The socialization that is carried out is not optimal, it will make it difficult for the management to achieve the goals and success of the Village FP program broadly. Based on the research findings, it shows that the socialization carried out by the Village FP Working Group in two villages namely Tanjung Rejo Village and Marjanji Tongah Village has not been carried out optimally.

The Working Group at this awareness stage should routinely socialize the Village FP program or activity, and invite the community to think together, analyze family and community problems in the village, and evaluate their limitations. These limitations can come from low capacity. This is important to do in order to map the solutions and needs desired by the wider community. At this awareness stage, it is also important to provide new education and knowledge as a foundation in carrying out further stages of empowerment such as regarding toddler health, education on the dangers of drugs, health for the elderly, and so on. Education is the transmission of knowledge to the community in order to be able to become a happy and prosperous family. In addition to providing education, the working group also provides assistance to the community to be able to generate motivation to participate in every Village FP activity. In addition, the community is introduced to community access and control to be able to take control of the resources in the village in a balanced way. As stated by the Chairman of the Galang District Family Planning that:

"We involve the people of the Village FP in every stage of planning, organizing, implementing and supervising activities in the Village FP. The local government organization are involved in this. The sense of ownership and responsibility of the community towards the sustainability of the Village FP is that we invite them in every Village FP activity, so that they feel they have and are responsible for the activities we do."

At this stage, it is evident that some of the people are aware and aware of several Village FP programs in their village. In addition, the community is also aware of the importance of maintaining the health of toddlers, adolescents, and the elderly.

\subsection{Training as an Effort to Build Skills and Strengthen Community Capabilities}

The potential strengthening stage aims to enable the Village FP community, both individually and in groups, to be able and empowered to achieve economic independence and knowledge. The stage of strengthening the potential or power can be done through various trainings, workshops and similar activities so that they have the skills to manage the opportunities available in the village. Training is a series of activities that aim to improve the skills, knowledge, experience, expertise, and change in an individual's attitude [14]. The training provided by the workong group to the community through the Efforts to Increase Prosperous Family Income unit is the provision of entrepreneurship training. The following is the opinion of respondents regarding the entrepreneurship training that has been provided by the working group to them, as shown in Table 4.2.

Tabel 4.2. The Village FP Provide Entrepreneurial Training to the Community

\begin{tabular}{|c|c|c|c|c|c|c|c|c|}
\hline \multirow{3}{*}{ Perception } & \multicolumn{6}{|c|}{ Village FP } & \multirow{2}{*}{\multicolumn{2}{|c|}{ Total }} \\
\hline & \multicolumn{2}{|c|}{$\begin{array}{l}\text { Marjanji } \\
\text { Tongah } \\
\text { Village } \\
\text { (Gunung } \\
\text { Meriah } \\
\text { District) }\end{array}$} & \multicolumn{2}{|c|}{$\begin{array}{c}\text { Tanjung } \\
\text { Rejo Village } \\
\text { (Percut Sei } \\
\text { Tuan } \\
\text { District) }\end{array}$} & \multicolumn{2}{|c|}{$\begin{array}{c}\text { Kramat } \\
\text { Gajah } \\
\text { Village } \\
\text { (Galang } \\
\text { District) }\end{array}$} & & \\
\hline & $\mathrm{F}$ & $\%$ & $\mathrm{~F}$ & $\%$ & $\mathrm{~F}$ & $\%$ & $\mathrm{~F}$ & $\%$ \\
\hline $\begin{array}{l}\text { Strongly } \\
\text { Disagree }\end{array}$ & 1 & 0,7 & 0 & 0,0 & 0 & 0,0 & 1 & 0,7 \\
\hline
\end{tabular}




\begin{tabular}{|l|c|c|c|c|c|c|c|c|}
\hline $\begin{array}{l}\text { Don't } \\
\text { Agree }\end{array}$ & 7 & 4,7 & 8 & 5,3 & 1 & 0,7 & 16 & 10,7 \\
\hline Doubtful & 27 & 18,0 & 30 & 20,0 & 20 & 13,3 & 77 & 51,3 \\
\hline Agree & 8 & 5,3 & 6 & 4,0 & 8 & 5,3 & 22 & 14,7 \\
\hline $\begin{array}{l}\text { Strongly } \\
\text { Agree }\end{array}$ & 7 & 4,7 & 6 & 4,0 & 21 & 14,0 & 34 & 22,7 \\
\hline Total & 50 & 33,3 & 50 & 33,3 & 50 & 33,3 & 150 & 100 \\
\hline
\end{tabular}

Source: Research data has been processed, 2021

Table 4.2 shows that, the 150 respondents who became the research sample, as many as 17 respondents $(11.3 \%)$ gave answers strongly disagree or disagree that Efforts to Increase Prosperous Family Income in this village has provided entrepreneurial training to the community. In addition, as many as 77 respondents (51.3\%) gave a doubtful answer. However, 56 respondents $(37.3 \%)$ stated that the management had provided entrepreneurial training to them. This finding shows that only a small proportion of respondents said that the Village FP Management had conducted entrepreneurship training. This means that the spirit of Village FP in empowering the family economy has not been realized optimally. The Village FP program which has a cross-sectoral concept has not been able to run. Ideally, each party (Local Government Organization) should take on their respective roles according to their main task and function for the welfare of the people of Village FP. However, this has not been done well. Still impressed that the Village FP Program is the main function of the Family Planning Organization. This is one of the obstacles that the Village FP is not yet optimal in carrying out its programs. This is confirmed by the respondents' views on the various collaborations carried out by the management of the Village FP Working Group with various stakeholders as shown in Table 4.3.

Tabel 4.3. The Village FP Has Collaborated With Stakeholders

\begin{tabular}{|c|c|c|c|c|c|c|c|c|}
\hline \multirow{3}{*}{ Perception } & \multicolumn{6}{|c|}{ Village FP } & \multirow{2}{*}{\multicolumn{2}{|c|}{ Total }} \\
\hline & \multicolumn{2}{|c|}{$\begin{array}{l}\text { Marjanji } \\
\text { Tongah } \\
\text { Village } \\
\text { (Gunung } \\
\text { Meriah } \\
\text { District) }\end{array}$} & \multicolumn{2}{|c|}{$\begin{array}{c}\text { Tanjung } \\
\text { Rejo Village } \\
\text { (Percut Sei } \\
\text { Tuan } \\
\text { District) }\end{array}$} & \multicolumn{2}{|c|}{$\begin{array}{l}\text { Kramat } \\
\text { Gajah } \\
\text { Village } \\
\text { (Galang } \\
\text { District) }\end{array}$} & & \\
\hline & $\mathrm{F}$ & $\%$ & $\mathrm{~F}$ & $\%$ & $\mathrm{~F}$ & $\%$ & $\mathrm{~F}$ & $\%$ \\
\hline \begin{tabular}{|l|} 
Strongly \\
Disagree
\end{tabular} & 0 & 0,0 & 0 & 0,0 & 0 & 0,0 & 0 & 0,0 \\
\hline \begin{tabular}{|l} 
Don't \\
Agree
\end{tabular} & 0 & 0,0 & 4 & 2,7 & 1 & 0,7 & 5 & 3,3 \\
\hline Doubtful & 16 & 10,0 & 33 & 22,0 & 27 & 18,0 & 76 & 50,7 \\
\hline Agree & 18 & 12,0 & 11 & 7,3 & 9 & 6,0 & 38 & 25,3 \\
\hline $\begin{array}{l}\text { Strongly } \\
\text { Agree }\end{array}$ & 16 & 10,7 & 2 & 1,3 & 13 & 8,7 & 31 & 20,7 \\
\hline Total & 50 & 33,3 & 50 & 33,3 & 50 & 33,3 & 150 & 100 \\
\hline
\end{tabular}

Source: Research data has been processed, 2021

Table 4.3. shows that of the 150 respondents who became the research sample, as many as 76 respondents
(50.7\%) gave a doubtful answer that the management had collaborated with stakeholders related to coaching or education and improving family businesses. In addition, as many as 69 respondents $(46.0 \%)$ gave an agree answer. The remaining 5 respondents $(3.3 \%)$ gave answers that they did not agree. This finding illustrates that respondents do not know if the management of Village FP has collaborated with other parties or only a small part of the community is aware of the cooperation carried out by the management with other parties. Although the working group Village FP. Management has collaborated with various stakeholders to conduct training, it has not been able to reach the entire village community, so only a part of the respondents (community) are involved in the training. The form of cooperation carried out by the management with multistakeholders in the implementation of Village FP includes providing training, implementing activities, community assistance, and providing assistance. The forms of multi-stakeholder cooperation in the management of Village FP can be seen in Matrix Table 4.1 .

Matriks 4.1. Multi-Stakeholder Cooperation in Village FP Management

\begin{tabular}{|c|c|c|c|c|c|c|}
\hline \multirow[b]{2}{*}{$\begin{array}{l}\mathrm{N} \\
\mathrm{O} .\end{array}$} & \multirow[b]{2}{*}{$\begin{array}{l}\text { Coope } \\
\text { ration }\end{array}$} & \multirow[b]{2}{*}{ Unit } & \multirow[b]{2}{*}{$\begin{array}{l}\text { Form of } \\
\text { cooperat } \\
\text { ion }\end{array}$} & \multicolumn{3}{|c|}{ Village FP } \\
\hline & & & & $\begin{array}{c}\text { Marj } \\
\text { anji } \\
\text { Ton } \\
\text { gah } \\
\text { Villa } \\
\text { ge }\end{array}$ & $\begin{array}{c}\text { Tanj } \\
\text { ung } \\
\text { Rejo } \\
\text { Villa } \\
\text { ge }\end{array}$ & $\begin{array}{c}\text { Kra } \\
\text { mat } \\
\text { Gaj } \\
\text { ah } \\
\text { Vill } \\
\text { age }\end{array}$ \\
\hline 1. & $\begin{array}{l}\text { Village } \\
\text { Institut } \\
\text { ion }\end{array}$ & $\begin{array}{l}\text { PKK, } \\
\text { Posya } \\
\text { ndu, } \\
\text { Comm } \\
\text { unity } \\
\text { Health } \\
\text { Center } \\
\text { s } \\
\text { Puske } \\
\text { smas) } \\
\text { Kepala } \\
\text { Dusun } \\
\text { dan } \\
\text { Comm } \\
\text { unity } \\
\text { Leader } \\
\text { s }\end{array}$ & $\begin{array}{l}\text { Impleme } \\
\text { nter of } \\
\text { Village } \\
\text { FP } \\
\text { Program } \\
\text { Activities } \\
\text { and } \\
\text { Extensio } \\
\mathrm{n}\end{array}$ & & & \\
\hline 2. & $\begin{array}{l}\text { Educat } \\
\text { ional } \\
\text { Institut } \\
\text { ion }\end{array}$ & $\begin{array}{l}\text { PAUD, } \\
\text { Univer } \\
\text { sity }\end{array}$ & $\begin{array}{l}\text { Providin } \\
\text { g } \\
\text { Training, } \\
\text { Such as } \\
\text { Training } \\
\text { on } \\
\text { Making } \\
\text { Breast } \\
\text { Milk } \\
\text { Comple } \\
\text { mentary } \\
\text { Foods. }\end{array}$ & & & \\
\hline
\end{tabular}




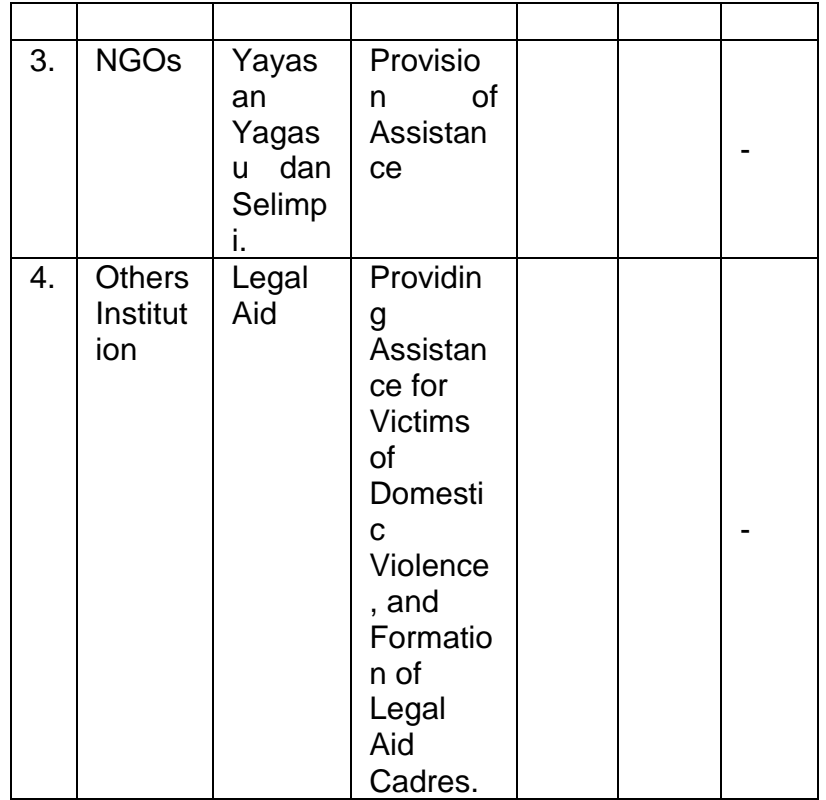

Source: Research data has been processed, 2021

Based on the form of cooperation carried out by the management, only Tanjung Rejo Village involves multistakeholder cooperation in the implementation of the Village FP program to the fullest, while other villages have very limited cooperation. Multi-stakeholder cooperation is important to get easy access, manpower and material assistance in achieving goals [15]. There are two units that play a significant role in providing training or workshops to village communities to strengthen their potential and power, namely the Development of Toddler Families (BKB) and the Efforts to Increase Prosperous Family Income (UPPKS) such as training in making masks, batik, and so on. This statement was conveyed by the Head of the Tanjung Rejo Village UPPKS Unit:

"People can take part in the training that we make such as sewing and batik or souvenirs, and this can increase income. Not all of our members are participating, because making batik requires patience."

In implementing the strengthening of community potential and power, the management does not walk alone. The Efforts to Increase Prosperous Family Income (UPPKS) is one of the group working Village FP units that contribute a lot in developing skills to develop entrepreneurship and achieve family economic improvement. There is a tendency that people who have skills are better able to improve the economy of their families than those who do not have skills [16]. In the implementation of this stage, the management is also assisted by the OPD in supporting the needs of the village community. The Village FP program policies must be supported by the role of competent and capable policy implementers for the success of a policy. Based on research findings, that the role of local government apparatus is quite large in supporting and assisting in the implementation of the Village FP program in Deli Serdang Regency. Furthermore, how the role that has been carried out by stakeholders to the village, this was also conveyed by the Chairman of the Galang District Family Planning regarding the role of stakeholders in the implementation of the Village FP program.

"P2KBP3A Service, Education Office, Manpower and Transmigration Service, Community Empowerment Agency Service, Agriculture Service, Fisheries and Marine Service, Social Service, Health Service, Ministry of Religion, Scouts, Police, and Security, and others.

The same statement was also conveyed by the Chairperson of the Percut Sei Tuan District Family Planning regarding the role of stakeholders in the implementation of the Village FP program activities:

"The implementation of the Village FP program is carried out across sectors, such as from the Agriculture Service in terms of providing seeds, from the Fisheries and Marine Service, from State Power Station such as installing electricity poles, and from the Public Works Department such as paving roads and castings.

A similar statement was also conveyed by the Chair of the Village FP Working Group in Kramat Gajah Village regarding the role of regional device in assisting the implementation of Village FP activities:

"Aid continues to flow from various agencies in Deli Serdang Regency, such as sanitation, making birth certificates, agricultural seeds and fish seeds, providing basic necessities, providing hearing aids and wheelchairs, as well as training on village mapping with satellite imagery and job-based training, competence to PKK and UPPKS."

Based on research findings, the role of regional divice in implementing the Village FP program activities includes socialization, coaching and training, providing assistance such as social fund assistance, assistance for agricultural plant seeds, providing easy access for children to obtain birth certificates and so on. The role of regional device in assisting the implementation of Village FP activities is also an important capital in supporting the successful management of the Village FP program. The findings of this study are in line with the results of research [17] which show the importance of collaboration with various regional device, such as data collection and making birth certificates and Identity Cards (KTP) carried out by Village FP administrators in several villages in Tanjungpinang City in collaboration with the Population and Civil Registry Office. Tanjungpinang City, shows the existence of inter-sectoral cooperation that has been built. Cooperation and government support that is not optimal in implementing the Village FP program will provide obstacles and problems to achieve the goals of a prosperous family [18].

\section{CONCLUSION}

From the results of the discussions that have been reviewed in the previous section, conclusions can be drawn, namely: the implementation of the Village FP 
program in the empowerment process includes awareness by providing socialization, education, and discussions with village communities. The Village FP administrators also provide entrepreneurship training assisted by village institutions, educational institutions, non-governmental organizations, and local government organizations in implementing the Village FP program policies. In addition, the administrators also involve skilled communities to educate and train other communities to improve their abilities. In general, the implementation of the Village FP program has been running quite well and has been well supported by various parties in Deli Serdang Regency, although it has not been carried out optimally.

\section{ACKNOWLEDGMENTS}

The authors gratefully acknowledge that the present research is supported by Kemristek-BRIN and Universitas Sumatera Utara of Year 2021.

\section{REFERENCES}

[1] Badaruddin, Erika Revida, Ermansyah, and Iskandar Muda. (2017). Village Governance with Implementation of Law Number 6 of 2014 on the Village and Village Administration. Dalam International Journal of Economic Research, Serials Publications Pvt. Ltd. Vol. 14, No.17, 2017.

https://www.researchgate.net/publication/3224921 66 Village governance with implementation_of law number_6 of 2014 on the village and villa ge administration

[2] Badaruddin, Kariono, Ermansyah, Lina Sudarwati. (2017). Community Empowerment Based Social Capital and Village Business Company (BUMDes). Proceedings of the $2^{\text {nd }}$ International Conference on Social and Political Development (ICOSOP 2017). Advances in Social Sciance, Education and Humanities Research (ASSEHR), Volume 136. Published by Atlantis Press. https://www.atlantispress.com/proceedings/icosop-17/25892080

[3] BKKBN. (2016). Pembentukan Kampung KB.

[4] Kementrian Komunikasi dan Informatika Republik Indonesia. (2017). Kampung KB: Inovasi Strategis Memberdayakan https://kominfo.go.id/index.php

[5] BKKBN. (2020). Kampung KB.

[6] Zubaedi. (2007). Wacana Pembangunan Alternatif: Ragam Perspektif Pengembangan dan Pemberdayaan Masyarakat. Jakarta: Ar Ruzz Media.

[7] Noor, Munawar. (2011). Pemberdayaan Masyarakat. Jurnal Ilmiah CIVIS. Vol. 1 (2). Hal. 87-99.
[8] Muslim, Aziz. (2012). Dasar-dasar Pengembangan Masyarakat. Yogyakarta: Samudera Biru.

[9] Ife. J. (1995). Community Development: Creating Community Alternatives-Vision, Analysiis and Practice. Melbourne: Longman.

[10] Ife, J. and Frank Tesoriero. (2008). Community Development: Alternatif Pengembangan Masyarakat Di Era Globalisasi, Penerjemah, Satrawan Manurung, Nurul Yakin, M. Nursyahid. Yogyakarta: Pustaka Pelajar.

[11] Creswell, John. (2004). Research Design Qualitative and Quantitative Approach. Thousand Oaks. London-New Delhi. Sage.

[12] Badaruddin Badaruddin, Kariono Kariono, Ermansyah Ermansyah \& Lina Sudarwati (2020): Village Community Empowerment Through Village Owned Enterprise Based On Social Capital In North Sumatera, Asia Pacific Journal of Social Work and Development, DOI: 10.1080/02185385.2020.1765855

[13] Riyadi, Agus. Dkk. (2020). Dinamika Pendekatan Dalam Penanganan COVID-19. Pekalongan. PT. Nasya Expanding Management.

[14] Rozalena, A., \& Dewi, S. K. (2017). Manajemen pendidikan dan pelatihan bagi karyawan. Jakarta: Raih Asa Sukses.

[15] Wiyono, Agung. dkk. (2006). Kehutanan Mulitipihak: Langkah Menuju Perubahan. Bogor. Center For International Forestry Research (CIFOR).

[16] Kariono, Badaruddin. Humaizi. (2020). A Study Of Women's Potential And Empowerment For Accelerating Village Development In Serdang Bedagai district, North Sumatera Province. Community, Work \& Family, DOI: 10.1080/13668803

[17] Rianto, F., Nengsih, NS, \& Setyadiharja, R. (2019). Evaluasi Program Kampung Keluarga Berencana di Kota Tanjungpinang. Jurnal Dimensi , 8 (2), 286-306.

[18] HM, R., \& Indrawadi, J. (2019). Implementasi Program Kampung KB dalam peningkatan Kesejahteraan Masyarakat di Kelurahan Gunung Pangilun Kecamatan Padang Utara Kota Padang. Jurnal Pendidikan Kewarganegaraan , 2 (3), 295 301. https://doi.org/10.24036/jce.v2i4 